bacteria, resistant to conventional antibiotics. However, some cytotoxicity of the peptides towards host cells limits their use in medicine and points to the necessity of creation of AMPs analogs with optimized features. Our work is aimed to the analysis of the antimicrobial activity of structural analogs of proline-rich AMPs of the domestic goat Capra hircus leukocytes - bactenecins ChBac3.4 ChBac5 and ChBac7.5 against drug-resistant clinical isolates of gram-negative bacteria (Pseudomonas aeruginosa MDR 522/17, E. coli ESBL 531/17, Acinetobacter baumannii 7226/16, Klebsiella pneumonia 344/17) and examination of their hemolytic properties towards human erythrocytes. The broth microdilution assay was used to evaluate the minimal inhibitory concentrations (MIC) of chemically synthesized peptides, and it was shown that truncated variants of ChBac5 $\left(1-23-\right.$ sequence from the $1^{\text {st }}$ to $23^{\text {rd }}$ amino acid residues) and ChBac3.4 (1-14) exerted a low activity in comparison with that of the full length peptides, while the peptide ChBac3.4 (1-19) had a significantly higher efficacy against all tested bacteria. We found that adding a fragment Arg-Phe-Arg to the peptides $\mathrm{N}$-termini increased the antibacterial properties of the full length ChBac3.4, and to a much lesser extent of the truncated bactenecins. A significance of the His-including region (14-18) of ChBac3.4 has been explored: the peptide with modification in this region and a lack of His residue possessed a potent antimicrobial activity. The highest antibacterial effect was observed in the case of a chimeric peptide including $\mathrm{N}$-terminal fragment of $\mathrm{ChBac} 7.5$ and a cystein-containing fragment of protegrin 1 (MICs of $0.5-4$ microM). Analysis of the hemolytic activity of the studied AMPs revealed that all the peptides do not cause lysis of human erythrocytes in a range of concentrations from 1 to 100 microM, except of the chimeric peptide that induced a significant lysis of red blood cells. The structural-activity analysis of caprine bactenecins revealed most promising AMPs with potent antibacterial activity and a lack of the cytotoxic effects for human cells (in particular, analogs of ChBac3.4 with modification in 14-18 amino acids region) that point to the prospect of the further investigation of caprine batenecins aimed to the creation the novel pharmaceuticals to combat antibiotic-resistant bacteria.

This work was supported with RFBR grant No. 17-04-02177.

10.4

doi: 10.15789/2220-7619-2018-4-10.4

\section{ANTI-INFLAMMATORY EFFECT OF ITRACONAZOLE IN PATIENTS WITH ALLERGIC BRONCHOPULMONARY ASPERGILLOSIS}

Y.I. Kozlova, E.V. Frolova, A.E. Uchevatkina, L.V. Filippova, N.N. Klimko

North-Western State Medical University named after

I.I. Mechnikov, St. Petersburg, Russia

The aim was to study the dynamics of immunological parameters in patients with ABPA on the background of the antifungal therapy.

The study included 11 patients with ABPA at the age from 29 to 78 years (median - 36 years). Allergological examination included skin tests with an allergens $A$. fumigatus ("Allergopharma", Germany). The levels of total IgE ("Polignost", Russia) and specific IgE (sIgE) to fungal allergens ("Alcor Bio", Russia) in serum were determined by enzyme immunoassay. Spontaneous production of interferon- $\gamma($ IFN $\gamma)$ was determined in the culture supernatant of cells without the addition of inducers. To assess the mitogen-induced production of IFN $\gamma$, blood cells were incubated for 24 hours with PHA at a concentration of $50 \mathrm{mg} /$ $\mathrm{ml}$ ("Sigma" USA). The production of IFN $\gamma$, activated by the allergen A. fumigatus ("Alcor Bio", Russia) at a concentration of $10 \mu \mathrm{g} / \mathrm{ml}$, was determined on day 6 . The resulting supernatants were used to determine spontaneous and induced IFN $\gamma$ production by enzyme immunoassay using commercial test systems ("Vector-Best", Russia).

The prick test with $A$. fumigatus was positive, levels of sIgE to $A$. fumigatus (Me $1.56(0.36 \div 10.56) \mathrm{IU} / \mathrm{ml})$ and total $\mathrm{IgE}(\mathrm{Me} 986(873 \div 1695) \mathrm{IU} / \mathrm{ml})$ were elevated in all ABPA patients. In the analyzed cases, according to the chest CT scans, focal and segmental lung infiltrations were detected in $6(55 \%)$ patients, bronchiectasis - in $5(45 \%)$. During the study, patients with ABPA were treated with itraconazole at a dose of $400 \mathrm{mg}$ per day. In all patients after of therapy significant clinical effect was noted: decrease in dyspnea and cough, improvement in the lung function, and positive dynamics in chest CT scans. At a re-examination at 12 weeks, all patients had a statistically significant decrease in the level of sIgE to A. fumigatus (Me $0.66(0.01 \div 5.24) \mathrm{IU} / \mathrm{ml}, \mathrm{p}=0.003)$ and total $\mathrm{IgE}(\mathrm{Me}$ $540(73 \div 613) \mathrm{IU} / \mathrm{ml}, \mathrm{p}=0.003)$. Was identified increased ability of blood cells to produce IFN $\gamma$ in response to PHA stimulation of the blood cells $(1914(1294 \div 2232)$ vs 910 $(852 \div 1648) \mathrm{pg} / \mathrm{ml}, \mathrm{p}=0.004)$ and to induction by the $A$. $f u$ migatus allergen $(48.0(24.0 \div 61.0)$ vs $19.0(2.0 \div 34.0) \mathrm{pg} / \mathrm{ml}$, $\mathrm{p}=0.001)$. The absolute number of eosinophils decreased $(\mathrm{p}=0.05)$

The tendency towards normalization of the immunological profile of patients in association with clinical signs improvement indicates the successful use of antifungal therapy in patients with ABPA.

10.5 doi: 10.15789/2220-7619-2018-4-10.5

\section{SAPONIN TAUROSID Sx1 ADMINISTRATION ENHANCES ANTIBODY PRODUCTION IN MICE, CHALLENGED WITH INFLUENZA VIRUS OR IMMUNIZED WITH INFLUENZA GRIPPOL ${ }^{\circledR}$ VACCINE}

V.Yu. Maligina ${ }^{1}$, I.B. Andronovskaja ${ }^{1}$, Yu.L. Krivorutchenko ${ }^{1}$, V.I. Grishkovetz ${ }^{2}$

${ }^{I}$ Medical Academy named after S.I. Georgievsky of Vernadsky Crimean Federal University, Simferopol, Russia, ${ }^{2}$ Taurida

Academy of Vernadsky Crimean Federal University, Simferopol, Russia

Several saponins demonstrate antiviral and immune potentiating properties. In this work the influence of saponin Taurosid Sx1 on the anti-hemagglutinin (H) antibodies production has been studied in influenza virus (IV) challenged or GRIPPOL ${ }^{\circledR}$ vaccinated mice.

BALB/c mice were challenged intranasally with $50 \mu \mathrm{l}$ $\left(10 \mathrm{LD}_{50}\right)$ of the $\mathrm{A} / \mathrm{WSN} / 1 / 33(\mathrm{H} 1 \mathrm{~N} 1)$ virulent strain or immunized with polymer-subunit GRIPPOL ${ }^{\circledR}$ vaccine season 2005/2006. A standard vaccine dose contained per $5 \mu \mathrm{g}$ of $\mathrm{H} 1$ and $\mathrm{H} 3,11 \mu \mathrm{g}$ of $\mathrm{H}$ from the IV type B. Taurosid Sx1 saponin was derived from Hedera taurica Carr. (Araliaceae). The blood serum levels of anti-H antibodies had been determined by Hemagglutination Inhibition (HI) test with the virulent $\mathrm{A} / \mathrm{WSN} / 1 / 33(\mathrm{H} 1 \mathrm{~N} 1)$ strain or standard kits of IV diagnostic strains (DS). Mice were vaccinated intramuscularly (i.m.) with $0.1 \mathrm{ml} \mathrm{10}$-times diluted vaccine. Control group was given isotonic sodium chloride saline solution (ISS). Within 3 days after vaccination or the virulent IV challenge animals were given $200 \mu \mathrm{g} /$ mouse/day of saponin orally. Control mice were given ISS. Statistical analyses was based on a middle means of the reverse titers of anti-H antibodies calculations $(\mathrm{M} \pm \mathrm{m})$, and an unpaired two sample Student-t test. $\mathrm{P}$ values of $\mathrm{P} \leq 0.05$ were considered as significant $(*)$. 
A significant increase of anti- $\mathrm{H}$ antibody titers in mice challenged with the virulent A/WSN/1/33(H1N1) strain and treated with Taurosid Sx1 was seen on the day 4, compare with the control group (128.0 $\pm 19.6^{*}$ and $80.0 \pm 15.1$, correspondently). By the day 14 the difference was not significant. When vaccinated mice were given Taurosid Sx1, the rising of anti-H1 antibody titers was not significant on the day 4 , but increased significantly 10 times to compare with the control group antibody titers by the day 14 $\left(1280.0 \pm 286.2^{*}\right.$ and $120.0 \pm 25.3$, correspondently). Oral administration of Taurosid Sx1 stimulated also production of antibody against IV type B hemagglutinin of DS on the day $4(100.0 \pm 20.0 *$ versus $40.0 \pm 0.0$ in control). Use of the saponin did not influence significantly on the anti-H3 antibody production.

This study has shown that oral administration of $200 \mu \mathrm{g} /$ mouse/day Taurosid Sx1 within 3 day after virulent IV challenge or GRIPPOL ${ }^{\circledR}$ vaccination selectively stimulates development of anibodies specific to IV type B hemagglutinin and anti-H1 anibodies generated by both virus infection and vaccination.

\section{6 \\ ANTIBACTERIAL ACTIVITY OF SYNTHESIZED COMPOUNDS FROM DIFFERENT CLASSES OF CHEMICALS \\ E.V. Rogacheva ${ }^{1}$, L.A. Kraeva ${ }^{1,2}$, G.N. Khamdulaeva ${ }^{1}$, V.P. Chelibanov ${ }^{3}$ \\ ${ }^{1}$ St. Petersburg Pasteur Institute, St. Petersburg, Russia; \\ ${ }^{2}$ S.M. Kirov Military Medical Academy, St. Petersburg, Russia; \\ ${ }^{3}$ St. Petersburg National Research University \\ of Information Technologies, Mechanics and Optics, \\ St. Petersburg, Russia}

The main problem in bacteriology is a constant increase a number of antibiotic-resistant strains of bacteria. Therefore, the purpose of our work is the study of new developed chemicals.

We investigated the antibacterial effect of three groups of compounds derived from synthetic and natural substances: 2 groups are based on fluoroquinolonic acid (30 substances) and derivatives of 1.2,4-triazoles (25 substances). The third compound (CH-II) is synthesized from natural substances (there is a patent). It contains organic components: pyrogallol, glycerol, succinic acid, tannins, gallic acid, mannose, fructose, myo-inositol, glucose, ribitol and microelements and minerals includes about 60 names. As a model, we used reference strains of microorganisms and isolated in hospitals (with multiple resistance): Esherichia coli, Klebsiella pneumonia, Pseudomonas aeruginosae, Staphylococcus aureus, Staphylococcus epidermidis, Enterococcus faecalis, Moraxella catarrhalis, Corynebacterium diphtheriae. The sensitivity to preparations was studied by the method of the minimum inhibitory concentration (MIC) in accordance with the recommendations of EUCAST 8.0.

Several substances from the first group of compounds showed very good results with reference strains: MIC for all representatives of Enterobacteriales was less than $0.1 \mathrm{mg} / \mathrm{l}$, for Staphylococcus spp. less than $0.5 \mathrm{mg} / 1$, E. faecalis $2 \mathrm{mg} / 1$, M. catarrhalis $0.1 \mathrm{mg} / 1, C$. diphtheriae $1 \mathrm{mg} / 1$. All reference and hospital strains were sensitive to this group.

Several substances from the second group of compounds also showed good results: MIC for different representatives of Enterobacteriales was different, but did not exceed $0.3 \mathrm{mg} / 1$, for Staphylococcus spp. less than $0.5 \mathrm{mg} / 1$, E. faecalis $4 \mathrm{mg} / 1, M$. catarrhalis $0.2 \mathrm{mg} / 1, C$. diphtheriae $2 \mathrm{mg} / \mathrm{l}$. For all reference strains, the results were in the sen- sitivity zone. The best results among hospital strains were obtained on Grampositive bacteria: they were all sensitive.

The compound $\mathrm{CH}-\mathrm{II}$ has good bactericidal properties. However, its MIC for all bacteria is slightly higher and is within the limits of intermediate values. This does not preclude the recognition of $\mathrm{CH}-\mathrm{II}$ as an effective compound, since it is theoretically and practically (in toxicological researches) shown to be harmless when using the concentrations obtained.

Thus, the new groups of compounds obtained have a good antibacterial activity at MIC and can in the future take a worthy place among drugs with antibacterial action.

10.7

doi: 10.15789/2220-7619-2018-4-10.7

\section{DEVELOPMENT OF MAGNETICALLY CONTROLLED ANTIBACTERIAL COMPLEX EFFECTIVE AGAINST BIOFILMS}

V.I. Rumyantceva, U.I. Andreeva, A.S. Drozdov, V.V. Vinogradov, E.I. Koshel

St. Petersburg National Research University of Information Technologies, Mechanics and Optics, St. Petersburg, Russia

The problem of effective therapeutic treatment of chronic and acute inflammation caused by the microbial biofilms development and vital activity is still actual today due to the resistance of bacteria to the most frequently antibiotic substances used in the medical practice. For recent years there are the most promising to use nanocomposite materials that can penetrate into the biofilms internal environment in a lightweight way. In particular magnetic particles in the composition of antibacterial agents can increase its effectiveness. Thus, the purpose of this work was to develop a new composite material with magnetically controlled properties and high antimicrobial activity.

As the main frame material was chosen amorphous calcium carbonate which entrapped ciprofloxacin. Composite matrix also consists of magnetite nanoparticles giving it magnetic properties. The active substance targeted release from nanocomposite occurs through calcium carbonate magnetoinductive recrystallization under the high frequency magnetic field action.

Experimental studies conducted on biofilms of two types of bacteria (gram-positive Staphylococcus aureus and gram-negative Escherichia coli) also proved a well-manifested composite based on calcium carbonate and magnetite antibacterial effect. The antibiotic in its initial form showed less effect on bacteria compared to the drug with immobilized antibiotic: the difference was $24-38 \%$ against $E$. coli and $50-76 \%$ against $S$. aureus. The antibacterial effect was also exerted by unentrapped nanocomposite particles without antibiotic which makes it possible to judge the possibility of providing a synergistic effect.

Thus, increasing the effectiveness of antibiotic substances on bacterial biofilms can be achieved (1) due to the nanocomposite magnetic targeting into which it is entrapped and its maximum localization in the inflammation focus, (2) due to the composite magnetic attraction into the biofilm and easier antibiotic penetration into biofilm because of its partial disintegration and (3) due to the synergistic effect in the form of biofilm local alkalization.

Further research is aimed at optimizing the method of obtaining an effective magnetically controlled drug and a comprehensive study of its impact on bacteria species biofilms the most important in medical practice as well as to assess its biocompatibility.

This work was supported by the Ministry of Education and Science of the Russian Federation (Project 4.8955.2017/8.9) 